ROCZNIKI NAUK SPOŁECZNYCH

Tom 13(49), numer $1-2021$

DOI: https://doi.org/10.18290/rns21491.9

JUSTYNA SZULICH-KAŁUŻA

\title{
TOŻSAMOŚĆ RELIGIJNA W DOBIE MEDIATYZACJI RELIGII
}

\author{
WPROWADZENIE
}

Dorobek naukowy Leona Dyczewskiego stanowi intelektualną przestrzeń i horyzont odniesień dla refleksji nad tożsamością i jej odmianami ${ }^{1}$. Studia teoretyczne i badania empiryczne różnych odsłon tożsamości były wiodącymi tematami projektów naukowych Katedry Socjologii Kultury KUL, którą przez wiele lat kierował (Dyczewski, 2009a).

W pierwszej części artykułu jest omówiona koncepcja tożsamości religijnej L. Dyczewskiego, z wyakcentowaniem jej dialogicznej, dynamicznej, wielokontekstowej i wieloźródłowej koncepcji ulokowanej w nowoczesnych kontekstach życia społecznego. Następnie zostało przybliżone zagadnienie mediatyzacji religii - procesu, w którym media wyłaniają się jako niezależna instytucja, z własną logiką, do której instytucje religijne mniej lub bardziej się dostosowują. Co szczególnie istotne, w okresie pandemii COVID-19 mediatyzacja religii dotyczy niespotkanego wcześniej, religijnego kontekstu wykorzystania mediów internetowych w sytuacji kryzysowej. Refleksje na temat mediatyzacji posłużyły do poszukiwania odniesień i konsekwencji dla współczesnej tożsamości religijnej, zawężonej do koncepcji w ujęciu L. Dyczewskiego. W części trzeciej przeprowadzono empiryczną analizę dyskursów religijnych w Internecie, traktując przekazy jako produkty medialne konstruujące elementy treściowe tożsamości religijnej. Zgromadzony materiał badawczy traktowałam jako określoną przestrzeń komunikacji, w której prezentowane

Dr hab. JUSTYNA SzULICH-KAŁUŻA, prof. KUL - Instytut Dziennikarstwa i Zarządzania, Katolicki Uniwersytet Lubelski Jana Pawła II; adres do korespondencji: Al. Racławickie 14, 20-950 Lublin; e-mail: justyna.szulich-kaluza@kul.pl; ORCID: https://orcid.org/0000-0002-6845-168X.

${ }^{1}$ Przegląd innych obszarów zainteresowań i badań L. Dyczewskiego można znaleźć w części pierwszej, zatytułowanej Pola badawcze Ojca Profesora Leona Dyczewskiego, pozycji Halicka, Szafranek, Dakowic (2018). 
są różne stanowiska uczestników dyskursu, dostarczających pewnych ram oraz schematów postrzegania świata w odniesieniu do konkretnego przedmiotu dyskursu i dążących do zdominowania innych dyskursów za pomocą określonych technik językowych i perswazyjnych (Czyżewski i in., 1997, s. 10; Foucault, 2002, s. 8). Zasadniczy problem towarzyszący przedmiotowym refleksjom odnosi się do pytania, które elementy dyskursów religijnych dotyczą i mogą modelować zawartość treściową indywidualnych tożsamości religijnych.

\section{LEONA DYCZEWSKIEGO KONCEPCJA TOŻSAMOŚCI RELIGIJNEJ}

Kategoria tożsamości, należąca do podstawowych wymiarów życia społecznego człowieka i społeczności, jest przedmiotem licznych studiów socjologicznych oraz analiz teoretycznych ujmowanych w rozmaitych kontekstach i aspektach, zwłaszcza w wymiarze tożsamości zbiorowości oraz tożsamości osoby ludzkiej (Świątkiewicz, 2017, s. 13).

Warto na wstępie dokonać porządkującego zarysu teoretycznego o tożsamości, opierając się na pracach Leona Dyczewskiego. Szkic na temat tożsamości będzie porządkującym odniesieniem dla istnienia i specyfiki szczegółowych tożsamości - w szczególności najbardziej mnie interesującej tożsamości religijnej.

Problematyka tożsamości religijnej jawi się obecnie w innym kontekście niż kilkanaście lat wcześniej. W warunkach pluralizmu społeczno-kulturowego tożsamość religijna nie jest we współczesnym świecie tym, co jest dane - stałe i utrwalone, lecz tym, co jest zadane, dynamicznie i zmiennie kształtowane. Jednostki samodzielnie konstruują własne tożsamości, swoje światopoglądy, swój system wartości moralnej (Mariański, 2017, s. 21). Najważniejsze ustalenia definicyjne L. Dyczewskiego na temat tożsamości można zamknąć w kilku zasadniczych punktach. Po pierwsze, tożsamość jednostki lub grupy społecznej jest czymś stałym i ma swoistą strukturę, którą tworzą elementy centralne (czyli fundamentalne, stałe, niezmienne, identyfikacyjne) oraz elementy cechujące się względną zmiennością, które dopełniają te pierwsze, dodając im aktualności i barwności. Po drugie, L. Dyczewski wyróżnił pierwszorzędne i drugorzędne tożsamości społeczne jednostki. Pierwszorzędne są takie, które obejmują integralnie osobowość jednostki, wszystkie sfery i całość jej życia, nadają sens i trwają przez całe życie. Do takich tożsamości należą przede wszystkim tożsamość rodzinna, etniczno-narodowa i religijna. Drugorzędne tożsamości społeczne jednostki wiążą się z grupami 
społecznymi celowymi i nietrwałymi, przynależność do nich z zasady jest $\mathrm{z}$ wyboru, czasowa i nie wymaga pełnego zaangażowania, np. grupa sportowa, artystyczna, muzyczna. Po trzecie, tożsamość ma wyraźnie zarysowane centrum i peryferia (Dyczewski, 2015a, s. 10). Tożsamość jest czymś stałym i niezmiennym w swoim centrum, ale zmiennym na peryferiach. Częściowo jest zatem dana, a częściowo wypracowana, inaczej - konstruowana, negocjowana. Każda jednostka i zbiorowość żyją w bardzo bogatym treściowo i zmiennym otoczeniu. Tożsamość w wymiarze indywidualnym i społecznym kształtuje się i modyfikuje w procesie komunikacji z otoczeniem poprzez absorpcję jego różnorodnych elementów (Dyczewski, 2015a, s. 11).

Omawiając definicje tożsamości, L. Dyczewski wielokrotnie wskazuje na rolę i znaczenie wartości kulturowych, które uznaje za ważne, cenne, wręcz niezbędne elementy ją konstytuujące (Dyczewski, 1995, 2009b, s. 151-152, 2011, s. 102-115). Ze względu na podjęty temat w artykule szczególną uwagę należy skierować na religię, która zajmuje według L. Dyczewskiego wyjątkową pozycję w procesach tożsamościowych co najmniej z kilku powodów. Najważniejszym z nich jest jej transcendentny charakter i pełniona funkcja dostarczania treści i kryteriów do kształtowania obrazu człowieka i świata (Dyczewski, 2009b, s.151, 170, 2015b, s. 24-25). Myśl tę precyzyjne wyraził Peter Berger: „Religie teistyczne zapewniają o istnieniu «Innego», aksjologicznego Absolutu, na którym można polegać i który w wyjątkowy sposób potwierdza poczucie własnej wartości człowieka. [...] Bóg staje się wtedy najbardziej wiarygodnym i ostatecznym znaczącym innym" (1967, s. 37-38, cyt. za: Seul, 1999, s. 559). Religie, opierając się na wierzeniach metafizycznych i etycznych, są mocnym źródłem wartości, norm, wzorów zachowań, motywują do poszukiwania sensu życia, wywierają kluczowy wpływ na perspektywę i samoidentyfikację siebie, a religijność - wartość indywidualna oraz społeczna - jest ważnym czynnikiem zmian społecznych (Dyczewski, 2010, s. 367). Religia dostarcza jasnych i mocnych zasad do wyraźnego rozróżniania dobra i zła (Dyczewski, 2015a, s. 24). Wprawdzie w pracach nie padają słowa, że religia zapewnia najsilniejszy rodzaj tożsamości w wymiarze jednostkowym i społecznym, ale przyjęty przez L. Dyczewskiego kierunek rozważań pozwala na stwierdzenie, że normy i wartości religijne ze względu na ich odwołanie do transcendencji mają większe oddziaływanie na ludzi niż jakiekolwiek inne rodzaje oddziaływań. Jak trafnie określił Jeffrey Seul, ,[...] religie najsilniej zapewniają przewidywalność i ciągłość, której potrzebuje jednostka, aby zachować poczucie stabilności psychicznej” (1999, s. 558). Można przyjąć, że tożsamość religijna w koncepcji L. Dyczewskiego jest konstruowana na podstawie 
refleksyjnego podejścia do relacji z Bogiem i opiera się na religijnych dogmatach, wzorach osobowych, tekstach religijnych, symbolach, praktykach religijnych, wspólnych rytuałach i przeżyciach. „Świadoma i głęboko przeżyta tożsamość religijna daje odpowiedź na podstawowe pytania egzystencjalne i przyszłościowe, nadaje sens ludzkiemu życiu i rodzi postawę misyjną, rozumiane bowiem i przeżywane prawdy religijne dają poczucie szczęścia" (Dyczewski, 2015a, s. 13). Autor uważał, że w Polsce można zauważyć dwie niespójne tendencje. Pierwsza - to odchodzenie od regularnego wypełniania praktyk religijnych oraz wybiórczy stosunek do prawd i norm religijnych. Druga tendencja wskazuje na pewne ożywienie elementów utrwalających tożsamość religijną katolików. Zaliczył do nich: wzrost zainteresowania wartościami niematerialnymi, pogłębianie życia duchowego poprzez aktywne uczestnictwo w grupach i ruchach o charakterze religijnym, kształtowanie się elity religijnej bardziej świadomie łączącej przekonania religijne z życiem codziennym, otwarcie na ludzi odmiennych pod względem religijnym i gotowość do podjęcia $\mathrm{z}$ nimi dialogu, świadome stosowanie wartości, norm i wzorców zachowań religijnych w polityce, gospodarce, kulturze i środkach masowego przekazu (Dyczewski, 2015a, s. 21-22, 2015b, s. 30). Autor twierdził także, że współczesna tożsamość religijna jest inna niż wcześniej, mniej racjonalistyczna, bardziej zróżnicowana i zindywidualizowana, silnie związana $\mathrm{z}$ emocjami i otwarta na nadzwyczajność. Poddawana naciskom płynnej rzeczywistości, wymaga ciągłego konstruowania, jednak w obszarze wewnętrznej struktury w swej istocie pozostaje niezmienna i trwała w elementach konstytutywnych, decydujących o psychofizycznej jedności - proprium jednostki, a zmienna w elementach, które łatwo porzucić lub przyswoić i które mogą upodabniać jednostkę do innych grup (Dyczewski, 2015a, s. 11, 15, 26). Przyjmując te ustalenia, trzeba dostrzec nowy wymiar tożsamości, mianowicie jej dialogiczną, dynamiczną, wielokontekstową i wieloźródłową koncepcję ulokowaną w nowoczesnych kontekstach życia społecznego, które w głównej mierze są zdominowane przez kulturę medialną i procesy komunikacyjnego konstruowania rzeczywistości. L. Dyczewski napisał, że każda jednostka poznaje świat religijny na różnych etapach swojego życia, angażuje się i internalizuje pewne wartości, albo neguje i odrzuca, poszukując innych, bardziej atrakcyjnych (Dyczewski, 2015a, s. 26). Zwrócił uwagę na niebezpieczeństwo hybrydyzacji tożsamości religijnej, czyli swoistego synkretyzmu religijnego. „Wielu uważa, że można być katolikiem i chodzić do cerkwi prawosławnej, gdyż w niej ładnie śpiewają, w domu palić kadzidełka przed posążkiem Buddy, z hinduizmu przyjmować wiarę $\mathrm{w}$ reinkarnację i odwiedzać świątynie 
różnych religii” (tamże). W tych nieustannych wyborach niebagatelną rolę odgrywają różnorodne elementy z otoczenia społecznego, w tym także komunikowane treści, obrazy, reprezentacje i dyskursy medialne, które zmieniają sposób patrzenia i interpretowania rzeczywistości społecznej. Problemem staje się integrowanie religijnych wartości i norm moralnych z polityką, kulturą i systemem medialnym. Wpisuje się on w szersze zagadnienie kontekstów łączących media ze społeczeństwem, kulturą i religią oraz transformacjami społeczno-kulturowymi pod wpływem innowacji medialnych. Radosław Sierocki trafnie zwrócił uwagę, że pytania o religię w przestrzeni nowych mediów stają się pytaniami o formy i konsekwencje włączania mediów w działania związane $\mathrm{z}$ religią, $\mathrm{z}$ konstruowaniem i podtrzymywaniem religii jako instytucji społecznej w kulturze współczesnej lub o praktyki o charakterze religijnym podejmowane w związku z nowymi mediami (Sierocki, 2018, s. 68). Dalsze refleksje na temat mediatyzacji religii posłużą do próby poszukiwania odniesień i konsekwencji dla tożsamości religijnej z uwzględnieniem jej cech w ujęciu Leona Dyczewskiego.

\section{MEDIATYZACJA RELIGII \\ - KONCEPCJE, PRZEJAWY, KONSEKWENCJE}

Termin „mediatyzacja” jest centralnym pojęciem teorii podkreślających intensywny wzrost znaczenia mediów w społeczeństwie. Za autora pojęcia uważa się szwedzkiego socjologa i badacza mediów, Kenta Aspa, który zastosował go już w 1986 r., opisując relacje między mediami a polityką. Autor dostrzegł, że systemy polityczne w dużym stopniu są pod wpływem mediów i łatwo dostosowują się do ich wymagań (Asp, 1986, s. 359). Obecnie „mediatyzacja" jest terminem używanym w wielu kontekstach do scharakteryzowania wpływu mediów na różne zjawiska i sfery życia społecznego. Nielicznym badaczom udało się rozwinąć teoretyczne koncepcje w kierunku bardziej spójnego i precyzyjnego procesu społeczno-kulturowego (Krotz, 2001, 2007b; Hjarvard, 2004, 2008, 2013; Schulz, 2004). Friedrich Krotz zaliczył mediatyzację do metaprocesów, określając nimi zmiany, które w odróżnieniu od tradycyjnie definiowanych procesów nie mają usytuowania czasowego i nie są ograniczone do obszaru geograficznego, czy określonej kultury. Mediatyzacja według Krotza nie jest wyłącznie metaprocesem zdeterminowanym technologicznie, bowiem istotną rolę odgrywa w niej człowiek, a ona sama zmienia komunikację międzyludzką, oferując nowe możliwości komunikacyjne. 
Ludzie korzystający z nich na nowo konstruują komunikacyjnie swój świat (Krotz, 2007a, s. 259). Według kolejnego autora - Stiga Hjarvarda - mediatyzacja jest to dwustronny proces zaawansowanej w wysokim stopniu nowoczesności, w którym media z jednej strony wyłaniają się jako niezależna instytucja, z własną logiką, do której pozostałe instytucje społeczne powinny się dostosowywać. Z drugiej strony media stają się integralną częścią innych instytucji życia społecznego, gdyż coraz więcej instytucjonalnych działań jest wykonywanych poprzez interaktywne i masowe środki przekazu (Hjarvard, 2008, s. 105). Winfried Schultz powiązał procesy mediatyzacji z trzema funkcjami mediów: pierwszą - funkcją mediów jako przekaźnika, z ich technologicznymi możliwościami pokonywania odległości przestrzennych i czasowych, drugą - funkcją semiotyczną, rozumianą jako kodowanie i formatowanie komunikatów docierających do odbiorców, i trzecią - funkcją ekonomiczną w znaczeniu wartości rynkowej produktów medialnych (Schulz, 2004, s. 87). W swojej koncepcji autor wymienił cztery mechanizmy zmian społecznych, w których media odegrały kluczową rolę: 1) extension - w tym mechanizmie technologie medialne poszerzają naturalne granice ludzkiej komunikacji, są „przedłużeniem człowieka", pozwalają pokonać odległości, czas, wzbogacić ekspresję, przezwyciężają ograniczenia formatów, poprawiając jakość kodowania poprzez np. wierne oddanie obrazu, słowa, dynamikę, sensoryczność estetykę; 2) substitution - media zastępują działania i instytucje społeczne oraz ich niemedialny charakter, mediatyzacja powoduje, że działania niemedialne przybierają formę medialną; 3) amalgamation - technologie medialne nie tylko poszerzają oraz zastępują formy i działania niemedialne, lecz także łączą się, przenikają wzajemnie, zerwane są granice między mediami i „nie-mediami”, technologie medialne wplatają się w obszary życia codziennego, przenikają sferę zawodową, gospodarkę, politykę, kulturę, religię i sferę publiczną, korzystanie z mediów staje się integralną częścią życia prywatnego i społecznego jednostek, medialna definicja rzeczywistości łączy się ze społeczną definicją rzeczywistości; 4) accomodation - aktorzy życia społecznego są zmuszeni dostosować się do sposobu działania poszczególnych mediów, ich formatów i specyfiki, wywodzącej się z wymagań producenckich i gatunkowych, czyli do tzw. logiki mediów (Schulz, 2004, s. 88-89).

W literaturze medioznawczej można spotkać także porządkujące rozróżnienie pojęć: „mediacja” i „mediatyzacja” (Couldry, Hepp, 2013, s. 191; Guzek, 2017, s. 89-90). Mediacja to proces społeczny, w którym media wspierają przepływ dyskursów, znaczeń i interpretacji w społeczeństwach (Silverstone, 2002; Couldry, 2008). Powinna być ona utożsamiana z realizacją funkcji extension, 
w której media są kanałami przekazu treści, natomiast mediatyzacja - z wypełnianiem funkcji ,amalgamacji”, w której media aktywne współtworzą rzeczywistość społeczną (Leśniczak, 2019, s. 239). Możemy zatem mówić o nowym paradygmacie badania mediów, w którym są traktowane nie przez pryzmat tekstów i produktów medialnych, ale jako praktyka porządkująca inne do tej pory, „nie-medialne” praktyki (okres pandemii COVID-19 bardzo dobrze to potwierdza, np. w obszarze konsumpcji, edukacji, kultury i religii). Precyzując powyższe, węższe pojęcie mediatyzacji religii koncentruje się na relacjach, w jaki sposób media mogą wpływać na praktyki religijne i szerzej na poczucie tożsamości religijnej. Na poziomie ogólnym formułowane są tezy, że procesy te stają się coraz bardziej zależne od mediów (Harvard, 2013, s. 102). Stig Hjarvard wyróżnił trzy formy mediatyzacji religii, z których każda ma inny rodzaj ram instytucjonalnych. Pierwsza forma jest reprezentowana przez media religijne, które podejmują starania kształtowania wspólnot religijnych i wzmacniania tożsamości religijnej w wymiarze jednostkowym i grupowym. Drugą formą, nierozłączną z pierwszą, jest obszar aktywności dziennikarskich, w których religia jest głównym przedmiotem dyskursu odbywającego się w sferze publicznej (przede wszystkim dominujących dyskursów politycznych i kulturowych). Trzecią formę mediatyzacji Hjarvard połączył ze zjawiskami „banalizacji”, czyli swoistego utowarowienia, w których religia jest traktowana jako produkt kultury popularnej, służący rozrywce, osiąganiu indywidualnych korzyści i poczucia komfortu (Hjarvard, 2012, s. 23). Z drugiej strony warto dostrzec tendencje „od-masowienia” i indywidualizacji komunikacji przez media, które mogą przyczynić się do korzystnych projakościowych zmian. Nowe technologie medialne oferują swoim użytkownikom wysoki stopień samodzielnych wyborów treści medialnych i samostanowienia tożsamościowego - w znaczeniu określania siebie przez jakiś czynnik lub zespół czynników medialnych. Podczas gdy tradycyjne media dystrybuowały i rozpowszechniały standaryzowane przekazy anonimowej publiczności (allocution pattern), nowe media pozwalają swoim użytkownikom na bezpośrednie pobieranie materiałów i informacji według indywidualnych potrzeb i zainteresowań (consultation pattern). Rozpada się typowa masowa anonimowa publiczność na rozdrobnione fragmentaryczne grupy odbiorców tworzące społeczności wirtualne interaktywnie się komunikujące (conversation pattern) (Schulz, 2004, s. 94).

Badania nad wpływem mediów elektronicznych na wspólnoty religijne i kształtowanie tożsamości religijnej w obliczu globalnej pandemii COVID-19 nabierają nowego znaczenia. Można przypuszczać, że pojawiło się (i jest to ciągły proces) wiele modyfikacji praktyk społecznych spowodowanych oddziaływaniem 
mediów, także w zakresie: religia - media. Niemal wszystkie Kościoły i wspólnoty wyznaniowe, kierując się wskazówkami ochrony zdrowia publicznego, były gotowe do podjęcia zmian w obowiązujących praktykach religijnych. Ogólną tendencją było więc zawieszanie modlitewnych zgromadzeń masowych lub zdecydowane ich ograniczenia. W zapobieganiu rozprzestrzeniania się wirusa SARS-CoV-2 bardzo szybko powszechne stało się przeniesienie praktyk religijnych do świata wirtualnego i ich dostosowywanie do zaistniałej sytuacji kryzysowej. Transpozycja wiary religijnej do łatwo dostępnych zasobów online spowodowała pojawienie się nowych postaw i zachowań, które z całą pewnością możemy uznać za eksperymentalne praktyki religijne. Doświadczenie wirtualnej wspólnoty religijnej, humanizującej w czasie izolacji i odbywania kwarantann, doprowadziło do kształtowania się nowych typów więzi międzyludzkich na bazie przeżyć i doświadczeń religijnych zapośredniczonych technologicznie. W wirtualnej wspólnocie religijnej kościół przestał oznaczać fizyczną budowlę związaną z określonym miejscem fizycznie zlokalizowanym, a miał szansę stać się wspólnotą wiernych, wspieraną przez struktury sieciowych interakcji społecznych. To doskonały przykład sytuacji, w której zasoby Internetu nie są już tylko repozytorium wiedzy i informacji, ale przestrzenią społeczną, w której może funkcjonować na wzór wcześniej proponowanej religii sieciowej (Campbell, 2005a, 2005b). Eksploracja religijnych zachowań i postaw w nowych formach komunikacji internetowej, stopień, w jakim technologia cyfrowa przyczynia się do celebracji przeżyć religijnych, oraz poczucie przynależności wspólnotowej to zestaw zagadnień prawdopodobnie modelujących tożsamość religijną w okresie pandemii.

Mediatyzacja religii w okresie pandemii COVID-19 dotyczy niespotkanego wcześniej, globalnego kontekstu religijnego wykorzystania mediów internetowych w sytuacji kryzysowej ${ }^{2}$. Przed okresem pandemii mediatyzacja religii odnosiła się w głównej mierze do transpozycji religijnego języka werbalnego - mówionego i spisanego (modlitwy, pisma, księgi) i wizualnego (gesty, obrzędy, rytuały religijne) - na słowo drukowane. Obecnie spotykamy się z nową jakością, podyktowaną koniecznością przekładu praktyk religijnych na język wirtualny, który pozwala na połączenie w jedną jakość oddalenia przestrzennego, języka wizualnego, werbalnego i dźwiękowego (Parish, 2020, s. 3).

\footnotetext{
${ }^{2}$ Jeśli chodzi o korzystanie z ,religijnych” transmisji w mediach, badania CBOS na temat: Religijność Polaków w warunkach pandemii pokazały, że na przełomie maja i czerwca 2020 r. trzy piąte respondentów uczestniczyło we mszy św. za pośrednictwem telewizji (60\%), przeszło co piąta osoba oglądała transmisje mszy św. przez Internet (21\%), co piąta modliła się za pośrednictwem mediów (20\%), a 17\% słuchało mszy św. w radiu https://www.cbos.pl/SPISKOM.POL/2020/K_137_20.PDF [dostęp: 8.05.2010].
} 
Na marginesie warto dodać, że modyfikacje w obszarze form przekazu religijnego (np. wynalezienie druku i nowego środka komunikacyjnego w postaci drukowanych tekstów religijnych zwiększyło zasięg i dostęp wiernych do tych tekstów, w dalszej kolejności zmniejszyło udział osób duchownych jako pośredników w wymianie treści religijnych) zmieniały wyraźnie relacje między człowiekiem a Bogiem, jego transcendencją i boskością. Bóg dzięki podejmowanym zabiegom stawał się bytem ,,po ludzku” bardziej dostępnym, do którego można było zbliżyć się bez pośrednictwa osoby duchownej (Eisenstein, 1993). W okresie pandemii media interaktywne i cyfrowe stały się znaczącą platformą rozpowszechniania wiedzy religijnej, pozwalającą wielu osobom i ruchom religijnym na wyrażanie wiary oraz uczuć religijnych poza tradycyjnymi ramami Kościoła. Można przypuszczać, że kryzys pandemiczny dokonał i wciąż dokonuje zmian w kilku obszarach procesu mediatyzacji religii (np. kształt praktyk religijnych, autorytet instytucji religijnych, treść narracji religijnych oraz percepcja przekazów i komunikatów wysyłanych przez instytucje kościelne).

\section{DYSKURSY RELIGIJNE W INTERNECIE W OKRESIE PANDEMII COVID-19}

Interesującym zagadnieniem, uzupełniającym powyższe refleksje, wydaje się eksploracja wirtualnych treści narracji religijnych, które uznajemy za jeden z czynników modelujących tożsamość religijną, zgodnie z tezą L. Dyczewskiego mówiącą o tym, że każda jednostka (podobnie zbiorowość) żyje w bardzo bogatym treściowo otoczeniu i jej tożsamość religijna kształtuje się i modyfikuje w procesie komunikacji poprzez absorpcję różnorodnych elementów, także treściowych (Dyczewski, 2015a, s. 11). Pytanie o dyskursy religijne w mediach internetowych, ich tematy główne, zawartość szczegółowa (opisana ze wskazaniem częstotliwości pojawiania się pewnych wątków) pozwolą na charakterystykę komunikacyjnego otoczenia tożsamości religijnej. Dyskursy potraktowane są zatem jako pewne źródło treści i systemów znaczeń, z których można czerpać w procesie kontekstowego konstruowania tożsamości, zwłaszcza jej elementów peryferyjnych.

Przeprowadzona analiza zalicza się do typu analizy dyskursu zapośredniczonego komputerowo i ma charakter indukcyjny (bazuje na ilościowej analizie zawartości określonych wątków tematycznych w zebranym materiale). Dobierając materiał badawczy do analizy dyskursów religijnych, zdecydowałam 
się na się na wybór internetowych materiałów w zasobach najpopularniejszej wśród użytkowników internetowej wyszukiwarki Google (https://www.google.pl/). Według ogólnoświatowych rankingów plasuje się ona na pierwszym miejscu i odpowiada za ponad $92 \%$ całego ruchu poszukiwań i zapytań internautów w sieci ${ }^{3}$. Słowa kluczowe, religion i coronavirus $^{4}$, posłużyły do otrzymania listy stron internetowych, które są przez wyszukiwarkę uznane za najlepiej pasujące do sformułowanego hasła. Następnie wybrano 100 kolejnych, niepowtarzających się naturalnych wyników wyszukiwania (organic search). Algorytm wyszukiwarki odpowiada wyłącznie za wyświetlanie linków i ustalanie kolejności ich wyświetlania, choć oczywiście należy pamiętać, że zawartość merytoryczna strony, wykorzystanie określonych słów kluczowych, a także wiele innych czynników (np. nakładane niewidzialne filtry i inne mechanizmy selekcjonujące zawartość) wpływa na wyświetlanie się stron w określonej kolejności w wynikach wyszukiwarek ${ }^{5}$. Strony internetowe zarchiwizowano w dniu 25 września 2020 r. i następnie poddano je procedurze selekcji - wybrano materiały, w których pojawiły się treści dotyczące monoteistycznych religii: judaizmu, chrześcijaństwa i islamu. Analiza wstępna materiału źródłowego na podstawie zestawu kategorii (uszczegółowione są zamieszczone poniżej) pozwoliła na wyróżnienie trzech dyskursów: dyskursu o zagrożeniach, strachu i lęku, dyskursu kontestacji, złości i niezgody oraz dyskursu rezygnacji i smutku. Jednostką analizy były akapity publikacji, w których pojawiły się treści odpowiadające poszczególnym kategoriom, przynależnym do każdego z wymienionych dyskursów.

\subsection{DYSKURS O ZAGROŻENIACH, STRACHU I LEZKU}

Pierwszy dyskurs - o zagrożeniach, strachu i lęku - może się przyczynić do osłabienia poczucia tożsamości religijnej poprzez treści naruszające poczucie bezpieczeństwa i stabilizacji wyznawców danej religii (ograniczenia praktyk religijnych).

Kategorie dyskursu:

1. Wydarzenia, które wywołują strach/lęk.

2. Sytuacje, które wywołują strach/lęk.

3. Stany, które wywołują lęk/strach.

\footnotetext{
${ }^{3}$ https://rapidapi.com/blog/best-search-engines(dostęp: 25.02.2021); https://gs.statcounter.com/se arch-engine-market-share [dostęp: 25.02.2021].

${ }^{4}$ Pojęcie „słowo kluczowe” definiuję w znaczeniu informatycznym, jako słowo używane w systemie wyszukiwania informacji, które sygnalizuje zawartość dokumentu.

${ }^{5}$ https://marketingwsieci.pl/slownik-e-marketingu/wyniki-organiczne/ [dostęp: 25.02.2021].
} 
Wykres 1 ilustruje ilościową zawartość treściową wymienionych kategorii dyskursu.

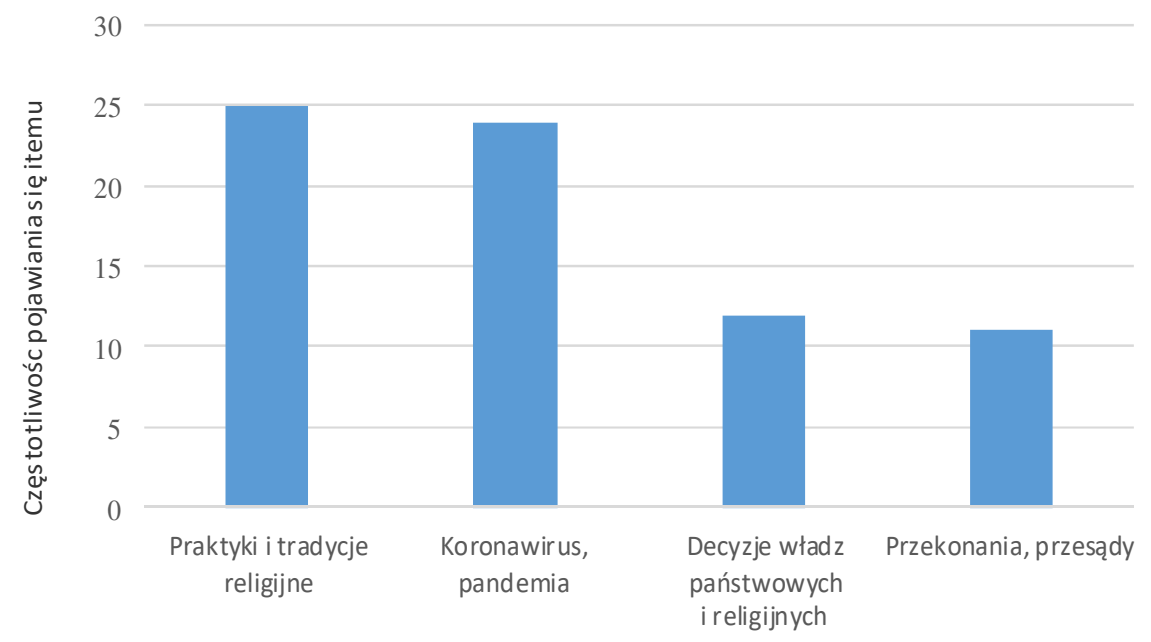

Wykres 1. Dyskurs o zagrożeniach, strachu i lęku

Źródło: opracowanie własne.

W dyskursie znalazły się elementy wywołujące poczucie zagrożenia - praktyki i tradycje religijne, a wśród nich np. uczestnictwo w Eucharystii (korzystanie z wody święconej, uścisk dłoni na znak pokoju podczas mszy św.), całowanie świętych ksiąg i mezuzy na framudze drzwi w judaizmie, pielgrzymki (np. do Mekki i Medyny czy na Jasną Górę), przynoszenie własnych dywaników do meczetów, podawanie ręki przez muzułman, odwiedzanie synagog, kościołów, meczetów; kulty zbiorowe, tłumne tradycyjne wesela ortodoksyjnych Żydów, pogrzeby rabinów, pochówki zmarłych w obrządku islamskim przy braku pozwolenia na kremację zwłok. Eksponowanym wątkiem tematycznym w przekazach jest sam wirus SARS-CoV-2. Autorzy przekazów przewidują, że pandemia przyspieszy upadek zinstytucjonalizowanej religii i jest poważnym zagrożeniem dla zachodniego chrześcijaństwa. Inne stany wymieniane w publikacjach w kontekście pandemii to lęk przed śmiercią, zarażeniem, chorobą, odejściem bliskich osób, bezrobociem, bankructwem, przed samotnością, blokada szans rozwoju, długotrwała izolacja, utrata sensu życia, zwątpienie w Bożą Opatrzność i ogólnie obawa o przyszłość świata. Decyzje władz państwowych i religijnych powodują izolację, zamknięcie granic, także przed pielgrzymami, nasilają dyskryminację grup marginalizowanych, w tym imigrantów, uchodźców 
oraz mniejszości rasowych i etnicznych. Charakteryzując treść dyskursu, warto wskazać na jeszcze jeden element zagrażający - przekonania i przesądy tzw. pseudoreligijnych interpretatorów, łączące pandemię z apokalipsą, z karą za niewłaściwe przestrzeganie zasad religijnych, z działaniem sił demonicznych oraz powoływaniem się na prywatne pseudoobjawienia i sny.

\subsection{DYSKURS KONTESTACJI, ZŁOŚCI I NIEZGODY}

Tematem drugiego wyróżnionego dyskursu jest kontestacja, złość i niezgoda na postawy osób oraz pewne sytuacje religijne wywołane pandemią. Ten dyskurs można potraktować z jednej strony jako wzmacniający, a z drugiej osłabiający tożsamość religijną.

Kategorie dyskursu:

1. Osoby, wobec których skierowana jest złość (podmiotowe obiekty złości).

2. Sytuacje, wydarzenia, stany, przedmioty materialne, wobec których skierowana jest złość (przedmiotowe obiekty złości).

3. Wydarzenia, sytuacje, stany, którym towarzyszy złość.

Wykres 2 ilustruje ilościową zawartość treściową wymienionych kategorii dyskursu.

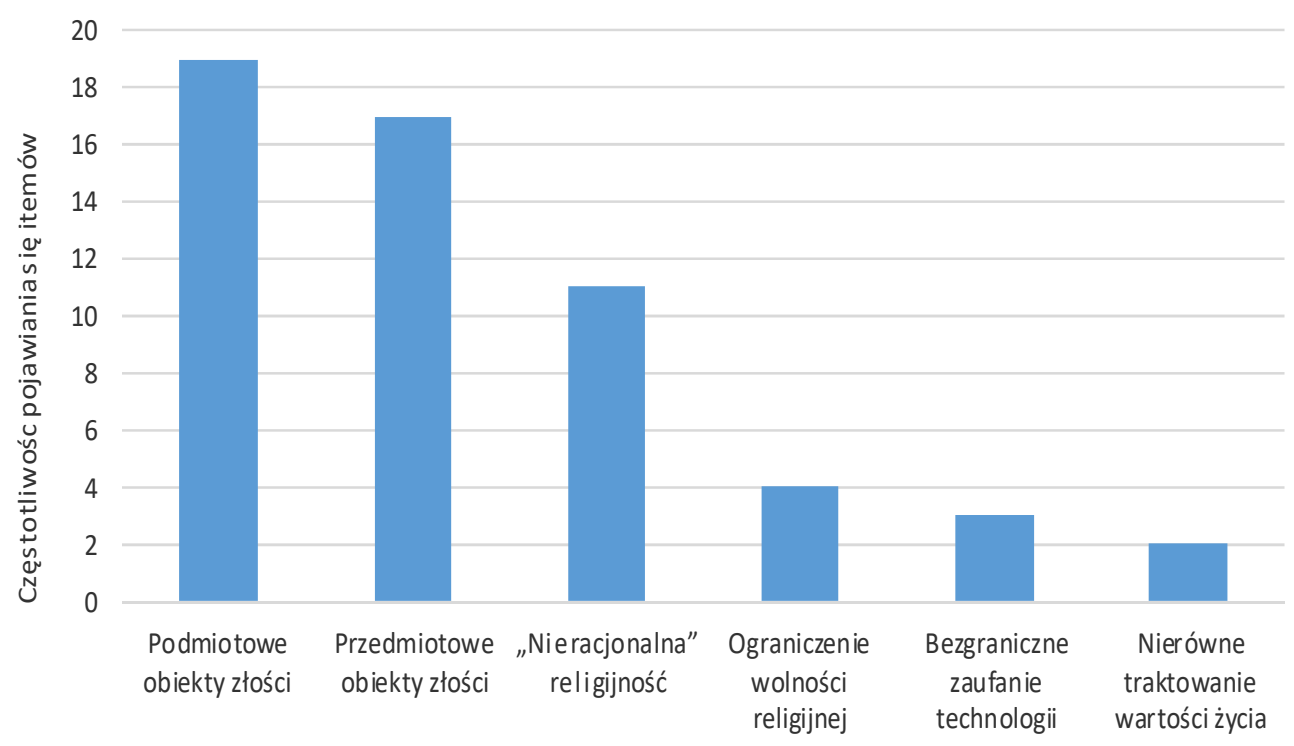

Wykres 2. Dyskurs kontestujący, złości, sprzeciwu, niezgody.

Źródło: opracowanie własne. 
W treściach dyskursu wymienione są liczne podmioty, przeciw którym skierowana jest złość, skutkująca obwinianiem ich za rozprzestrzenianie się pandemii. Należą do nich wierni, którzy robią z siebie broń biologiczną przez uczestnictwo w praktykach religijnych, osoby chore, które nie przestrzegają zaleceń izolacji i są obwiniane za sprowadzenie koronawirusa do wspólnot religijnych. Złość skierowana jest w stronę hierarchów za nieprzemyślane wypowiedzi, np. o dominacji wody święconej nad wirusem, świadczące o znikomych kompetencjach epidemiologicznych. Dyskurs treściowo wypełniają także przedmiotowe obiekty złości: koronawirus; pandemia, ingerowanie w dogmaty w religii prawosławnej; tora (masowo dotykana może stać się ogniskiem zakażeń); masowe modlitwy muzułman (ogniska epidemii); kwarantanny zabraniające udziału w ceremoniach religijnych, zwłaszcza pogrzebowych. Do elementów dyskursu należy zaliczyć także przejawy nieracjonalnej pobożności w okresie pandemii w wymiarze indywidualnym, które obejmują traktowanie Eucharystii jako antidotum na koronawirusa, pewnych praktyk religijnych jako zabezpieczenia czy nawet leku na COVID-19, a także przekonania, że pandemia jest gniewem Boga, rozpowszechnianie się koronawirusa nie wykracza poza zakres wszechmocy Bożej, a zatem nie może zagrażać wierzącym bez Jego zgody. Brak zgody wywołują także państwowe i lokalne ograniczenia dotyczące zgromadzeń religijnych. Są one traktowane jako ograniczania wolności religijnej i w kilku przypadkach stały się przedmiotem pozwów sądowych. Uzupełnieniem treści dyskursu są stwierdzenia o zbędności modlitwy i religii w czasie kryzysu oraz pochwała nieograniczonych możliwości postępu technologicznego, dzięki któremu ludzkość może odpowiedzieć na wszystkie dręczące ją pytania. Krytyce poddane jest także nierówne traktowanie wartości życia, wyrażające się w stwierdzeniu, że na południu naszego globu życie nie ma takiego znaczenia jak na bogatej północy.

\subsection{DYSKURS REZYGNACJI I SMUTKU}

Trzeci dyskurs nazwałam dyskursem rezygnacji i smutku, który może się przyczyniać raczej do osłabienia poczucia tożsamości religijnej.

Kategorie dyskursu:

1. Wydarzenie, sytuacje, stany, którym towarzyszy smutek.

2. Reakcje w wymiarze indywidualnym i zbiorowym, którym towarzyszy smutek (np. utrata kogoś, czegoś, nieosiągnięcie celu).

Wykres 3 ilustruje ilościową zawartość treściową wymienionych kategorii dyskursu. 


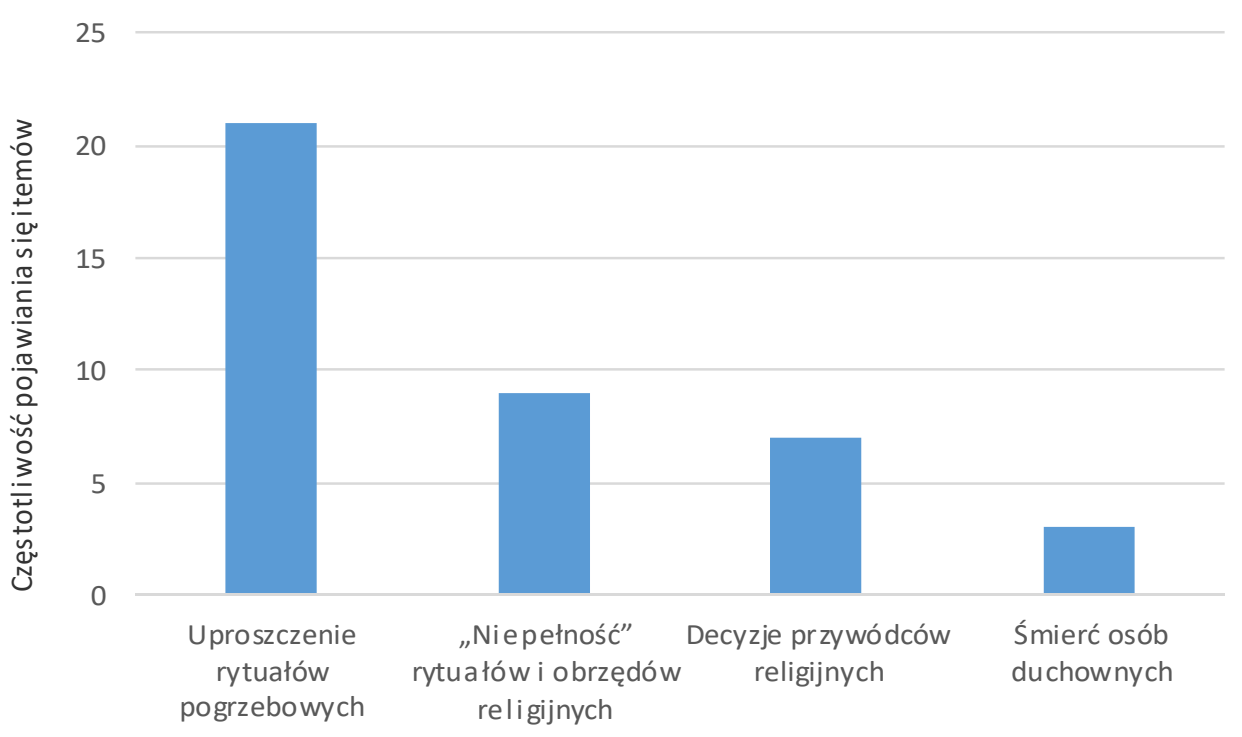

Wykres 3. Dyskurs rezygnacji i smutku.

Źródło: opracowanie własne.

Dyskurs rezygnacji i smutku zawiera w pierwszej kolejności tematy związane z ograniczeniem i uproszczeniem rytuałów pogrzebowych (pogrzeby w nielicznym kręgu rodzinnym; zazwyczaj pogrzeby to czas wspólnoty społeczności w obliczu straty - w okresie pandemii wiele pogrzebów odbywa się przy niewielkiej liczbie osób fizycznie obecnych, spotykamy utrudnienia w opiece nad chorymi i wykonywania niektórych obrzędów odchodzenia i pochówku; samotna śmierć wywołuje cierpienie, rodziny i społeczności w różnych zakątkach świata). Częstym tematem dyskursu są także wirtualne praktyki religijne, które cechuje „niepełność” przejawiająca się w braku wspólnotowego życia religijnego i istotnego, wspólnotowego wymiaru kultu. Kolejnym wątkiem tematycznym dyskursu jest brak fizycznej obecności wiernych na uroczystościach religijnych (samotna modlitwa w pustym Kościele, zamknięte kościoły, odwoływanie mszy św., zamknięte i puste meczety). Wielu uczestniczących w nabożeństwach czuje się zasmuconych szybkością, z jaką biskupi zgodzili się najpierw zakazać publicznych liturgii, a następnie zamknąc kościoły - dla katolików jest to szczególne bolesne. W dyskursie mieszczą się także informacje o śmierci osób duchownych, np. śmierć księdza Basilicio „Bachi” Briteza, znanego ze swojej pracy na rzecz ubogich w Argentynie. 


\section{PODSUMOWANIE}

Koncepcja tożsamości religijnej o. prof. Leona Dyczewskiego posłużyła w artykule za swoisty drogowskaz dla refleksji nad sposobami jej konstruowania i negocjowania uwzględniającymi różnorodne konteksty. Procesowi mediatyzacji religii poświęcono szczególną uwagę z powodu dynamiki jej zjawisk w okresie pandemii COVID-19 i niespotkanego wcześniej, globalnego religijnego wykorzystania mediów internetowych w sytuacji kryzysowej. Transpozycja wiary religijnej do łatwo dostępnych zasobów online spowodowała pojawienie się nowych postaw i zachowań, które z pewnością możemy określić eksperymentalnymi. Przyjęto, że nowe technologie medialne oferują swoim użytkownikom wysoki stopień samodzielnych wyborów treści medialnych, co można utożsamiać z przejawem samostanowienia tożsamościowego - w znaczeniu określania siebie przez jakiś czynnik/treść lub zespół czynników/treści medialnych. Analiza internetowych dyskursów religijnych, oparta na wyliczeniach częstotliwości pojawiania się pewnych wątków, pozwoliła na próbę wskazania czynników treściowych, przypuszczalnie mogących modelować tożsamość religijną. Podążając za tezą L. Dyczewskiego o niezmiennej tożsamości religijnej w swoim centrum, ale zmiennej na peryferiach można wskazać, że faktycznie $w$ analizowanych dyskursach nie ma mowy o zmianach czy naruszaniu prawd doktrynalnych, dekalogu wartości, świętych autorytetów czy modlitw (poza jednym wyjątkiem - dyskurs kontestacji głosi ich zbędność). Inne elementy tożsamości religijnej, zaliczane do peryferyjnych i mniej stałych, są poddane pewnym ocenom i wartościowaniu, a to z kolei może prowadzić do postawienia pytania o ich potrzebę zachowania w niezmienionej formie. Do grupy takich elementów zaliczyć można: postawy wobec praktyk religijnych, stosunek do określonych sytuacji i osób z kręgu religijnego, kształt religijnych interakcji społecznych. Z pewnością proces mediatyzacji religii oraz jej kontekst pandemiczny jest nowym doświadczeniem i jednocześnie wyzwaniem do modyfikowania indywidualnej tożsamości, a także samodzielnego wartościowania jej elementów.

\section{BIBLIOGRAFIA}

Asp K. (1986), Mäktiga massmedier: Studier i politisk opinionsbildning [Powerful mass media: studies in political opinion-formation], Stockholm: Akademilitteratur.

Barmania S., Reiss M.J. (2020), Religion and Science in a Time of COVID-19: Allies or adversaries?, https://blogs.scientificamerican.com/observations/religion-and-science-in-a-time-of-covid-19allies-or-adversaries/ [dostęp: 20.02.2021]. 
Berger P.L. (1967), The sacred canopy. Elements of a sociological theory of religion, Garden City, NY: Anchor Books.

Campbell H.A. (2005a), Exploring religious community online: We are one in the network, New York: Peter Lange.

Campbell H. (2005b), Spiritualising the internet. Uncovering discourses and narratives of religious Internet usage, Heidelberg Journal of Religions on the Internet, nr 1, s. 1-26.

Campbell H. (2007), Who's got the power? Religious authority and the Internet, Journal of Computer-Mediated Communication, nr 12(3), s. 1043-1062.

Couldry N. (2008), Mediatization or mediation? Alternative understandings of the emergent space of digital storytelling, New Media \& Society, nr 10 (3), s. 373-391.

Couldry N., Hepp A. (2013), Conceptualizing mediatization: Contexts, traditions, arguments, Communication Theory, nr 23, s. 191-202.

Czyżewski M., Kowalski S., Piotrowski A. (1997), Rytualny chaos. Studium dyskursu publicznego, Kraków: Aureus.

Dyczewski L. (1995), Kultura polska w procesie przemian, Lublin: Towarzystwo Naukowe KUL.

Dyczewski L. (2004), Społeczno-kulturowy kontekst religijności, [w:] K. Góźdź, K. Klauza, C. Rychlicki, H. Słotwińska, P. Szczur (red.), Kościót w życiu publicznym. Teologia polska i europejska wobec nowych wyzwań, Lublin: Wydawnictwo KUL, s. 225-228.

Dyczewski L. (2009a), Katedra Socjologii Kultury. Tożsamość społeczno-kulturowa $i$ komunikacja społeczna, [w:] S. Fel, J. P. Gałkowski, J. Zabielska (red.), Tradycja i wspótczesność. 90 lat socjologii w Katolickim Uniwersytecie Lubelskim, Lublin: Wydawnictwo KUL 2009, s. 153-161.

Dyczewski L. (2009b), Wartości kulturowe ważne dla polskiej tożsamości, [w:] L. Dyczewski, D. Wadowski (red.), Tożsamość polska $w$ odmiennych kontekstach, Lublin: Wydawnictwo KUL, s. $149-179$

Dyczewski L. (2010), Tożsamość Europy Środkowo-Wschodniej w procesach jednoczenia się Europy, [w:] L. Dyczewski, J. Szulich-Kałuża, R. Szwed (red.), Stałość i zmienność tożsamości, Lublin: Wydawnictwo KUL, s. 359-372.

Dyczewski L. (2011), Kultura w całościowym planie rozwoju, Warszawa: Instytut Wydawniczy PAX.

Dyczewski L. (2015a), Tożsamość religijna, [w:] L. Dyczewski, K. Jurek (red.), Tożsamość religijna w nowoczesności, Lublin: Wydawnictwo KUL, s. 9-27.

Dyczewski L. (2015b), Religion: Spirituality in modernity, [w:] L. Dyczewski (red.), Secularization and development of religion in modern society, Washington: The Council for Research in Values and Philosophy.

Dyczewski L. (2016), Sacrum w przestrzeni publicznej, [w:] J. Adamkowski, M. Tymochowicz, Sacrum $w$ kulturze tradycyjnej $i$ wspótczesnej, Lublin, Wrocław: Polskie Towarzystwo Ludoznawcze, Wydanictwo UMCS, s. 15-27.

Eisenstein E. (1993), The printing revolution in early modern Europe, Cambridge, New York, Melbourne, Madrid, Cape Town, Singapore, São Paulo: Cambridge University Press.

Foucault M. (2002), Porzqdek dyskursu, tłum. M. Kozłowski, Gdańsk: słowo/obraz terytoria.

Guzek D. (2017), Chrzest Polski w mediach, Studia Medioznawcze, nr 1, s. 89-101.

Halicka M., Szafranek A., Dakowicz L. (red.) (2018), Mistrz i Przyjaciel. Ojciec Profesor Leon Benigny Dyczewski OFMConv, Białystok: Wydawnictwo Uniwersytetu w Białymstoku. 
Hjarvard S. (2008), The mediatization of society. A theory of the media as agents of social and cultural change, Nordicom Review, nr 2, s. 105-134.

Hjarvard S. (2012), Three forms of mediatized religion. Changing the public face of religion, [w:] S. Hjarvard, M. Lövheim (red.), Mediatization and religion. Nordic Perspectives, Göteborg: University of Göteborg, s. 21-44.

Hjarvard S. (2013), The mediatization of culture and society, London, New York: Routledge.

Hojsgaard M.T. (2005), Cyber-religion: On the cutting edge between the virtual and the real, [w:] M.T. Hojsgaard, M. Wartburg (red.), Religion and cyberspace, London: Routledge, s. 50-63.

Krotz F. (2001), Die Mediatisierung kommunikativen Handelns. Der Wandel von Alltag und sozialen Beziehungen, Kultur und Gesellschaft durch die Medien, Wiesbaden: Westdeutscher Verlag.

Krotz F. (2007a), The meta-process of 'mediatization' as a conceptual frame, Global Media and Communication, nr 3, s. 256-260.

Krotz F. (2007b), Mediatisierung: Fallstudien zum Wandel von Kommunikation, Wiesbaden: VS Verlag für Socialwissenschaften.

Leśniczak R. (2019), Mediatization of institutional communication of the Catholic Church. Reflections on the margins of the migration crisis, Studia Medioznawcze nr 3, s. 237-246.

Luckmann T. (1996), Niewidzialna religia, Kraków: Zakład Wydawniczy „Nomos”.

Mayr O. (1986), Authority, liberty, and automatic machinery in early modern Europe, Baltimore: Johns Hopkins University Press.

Mariański J. (2017), Tożsamości religijne w społeczeństwie polskim. Studium socjologiczne, Toruń: Wydawnictwo Adam Marszałek.

McLuhan M. (1967), Understanding media: The extensions of man, London: Routledge and Kegan Paul.

Parish H. (2020), The absence of presence and the presence of absence: Social distancing, sacraments, and the virtual religious community during the COVID-19 pandemic, Religions, $\mathrm{nr} 6$, s. 1-15, doi:10.3390/rel11060276

Seul J. (1999), Ours is the way of God: Religion, identity, and intergroup conflict, Journal of Peace Research, nr 5, s. 553-569.

Schulz W. (2004), Reconstructing mediatization as an analytical concept, European Journal of Communication, nr 1, s. 87-101.

Sierocki R. (2018), Praktykowanie religii w nowych mediach. Katolicka przestrzeń Facebooka Toruń: Wydawnictwo Adam Marszałek.

Silverstone R. (2002), Complicity and collusion in the mediation of everyday life, New Literary History, $\mathrm{nr}$ 4, s. 761-780.

Świątkiewicz W. (2017), Przedmowa, [w:] J. Mariański, Tożsamości religijne w spoteczeństwie polskim. Studium socjologiczne, Toruń: Wydawnictwo Adam Marszałek, s. 13-16.

\section{Strony internetowe}

https://rapidapi.com/blog/best-search-engines [dostęp: 25.02.2021].

https://gs.statcounter.com/search-engine-market-share [dostęp: 25.02.2021].

https://marketingwsieci.pl/slownik-e-marketingu/wyniki-organiczne [dostęp: 25.02.2021]. 


\section{TOŻSAMOŚĆ RELIGIJNA W DOBIE MEDIATYZACJI RELIGII}

\section{Streszczenie}

Zasadniczym celem podjętym w artykule jest przedstawienie koncepcji tożsamości religijnej Leona Dyczewskiego w dobie mediatyzacji religii i pokazanie dynamiki procesu mediatyzacji w kontekście pandemii COVID-19. Tematyka wpisuje się w nurt współczesnego dyskursu o tożsamości religijnej w dobie pandemii, otwierając nowe interesujące pola problemowe. Artykuł ma trójdzielną strukturę - w pierwszej części jest omówiona koncepcja tożsamości religijnej w ujęciu Leona Dyczewskiego, następnie przybliżone zagadnienie mediatyzacji religii wraz z odniesieniami do najważniejszych konsekwencji dla tożsamości religijnej. W części trzeciej dokonano empirycznej analizy dyskursów religijnych w Internecie w okresie pandemii COVID-19. Przekazy są traktowane jako produkty medialne konstruujące elementy treściowe tożsamości religijnej.

Słowa kluczowe: tożsamość religijna; mediatyzacja religii; dyskursy religijne.

\section{RELIGIOUS IDENTITY}

IN THE ERA OF THE MEDIATIZATION OF RELIGION

\section{Summary}

The main goal of the article is to present Leon Dyczewski's concept of religious identity in the era of the mediatization of religion, and to describe the dynamics of this process in the context of the COVID-19 pandemic. The subject is an important part of the contemporary discourse on religious identity in the age of a pandemic and opens up new interesting problem issues. The article is divided into three parts. The first part discusses Dyczewski's concept of religious identity. Then I present the issue of the mediatization of religion and how it affects religious identity. Finally, I carry out an empirical analysis of religious discourses on the Internet during the COVID-19 pandemic. Messages are treated as media products that construct the content elements of religious identity.

Keywords: religious identity; mediatization of religion; religious discourses. 